\title{
Financial centre bias: another puzzling anomaly in the IPO market?
}

\author{
Dariusz Wójcik \\ School of Geography and St. Peter's College, Oxford \\ dariusz.wojcik@spc.ox.ac.uk
}

Draft June 2008

\begin{abstract}
This paper shows that firms from financial centres are more likely to go public than their provincial counterparts. The financial centre bias is analysed for 32 countries, including the European Union, the USA and Japan. It is particularly strong in countries with underdeveloped stock markets and closed corporate governance regimes, but it is still present in countries with the most developed stock markets and most open corporate governance, such as the UK and the USA. Reasons for the bias include the benefits of issuers' proximity to IPO intermediaries and specialised labour markets, corporate governance incentives, and cultural factors.
\end{abstract}

Keywords: IPOs, stock markets, financial centres, corporate governance, proximity

JEL classification: G30, R10

\section{Introduction}

Although Initial Public Offerings (IPOs) belong to the most publicised events on financial markets, and one of the most researched areas in finance and economics, little research has been conducted within these disciplines on the geography of IPOs within countries, as if it was assumed that geography of regions and urban centres did not matter for public equity markets. Such an assumption stands in stark opposition to the work of economic geographers, for whom diversity, heterogeneity, and differentiation within domestic financial markets are as important as those between markets. Their research has established that an important part of information used in financial markets is not easily transferable across space, resulting in the significance of local financial relations and spatial concentration of financial firms (Martin, 1999; Corbridge et al., 1994). The latter is further enhanced by localisation and agglomeration economies, whereby financial and related firms concentrate spatially in order to benefit from common infrastructure and labour markets. Beyond the role of information and economic incentives, geographers have documented the role of political, social and cultural factors in the formation of financial centres (Leyshon and Thrift, 1997), as well as systematic differences within domestic economies in terms of corporate ownership and governance (Clark and Wójcik, 2007). Thus, for economic geographers, mobility of capital within countries has always been restricted, and access to capital within countries, has always been uneven, with implications for the continued significance of local and regional equity markets (Klagge and Martin, 2005).

Recent empirical research in financial economics, however, starts to recognise that location within countries matters in public equity markets. The growing literature on 
'local bias' documents that investors' equity portfolios are skewed towards local firms and that this may be accompanied by the ability to obtain superior returns driven by access to information available to local but not to remote investors (for a review see Wójcik, 2008). Loughran and Schultz, for example, demonstrate that in the US rural firms trade less, are covered by fewer analysts, and are owned by fewer institutions than urban firms (2005). Their more recent inquiry builds on the information-based explanation of the 'local bias', claiming that companies located in urban areas have more potential shareholders than their rural counterparts, and as a result have better access to public equity markets (2006). Consistent with this hypothesis, they show that US rural firms wait longer to go public, are less likely to conduct seasoned equity offerings, use lower quality underwriters, and have more debt in their capital structure. This is an important finding, which will be expanded in this paper to show that access to local information is one of many aspects of the uneven geography of primary equity markets.

The objective of this paper is to contribute to the geography of primary public equity markets both theoretically and empirically. Conceptually, the paper combines insights from financial economics and economic geography, and enhances them with a highly relevant interdisciplinary debate on corporate governance. Just as the development of geographical economics by Paul Krugman and others have rested on adding the ideas of imperfect competition, increasing returns to scale, and agglomeration economies to the mainstream trade theory, so does recent research in financial economics rest on incorporating ideas about geography of information. In this paper, I intend to use the ideas of increasing returns to scale and agglomeration economies to explain the mechanisms of the primary public equity markets, but I also want to go beyond what we could call geographical finance, by considering genuinely social and cultural factors. This theoretical contribution is enhanced with comprehensive empirical coverage of public equity markets in 30 European countries as well as the USA and Japan, which is important given that existing research on IPOs is US-centric (Jenkinson and Ljungqvist, 2001).

I will argue that there are strong theoretical reasons and empirical evidence that provincial firms are less likely to go and be public than firms from financial centres. This phenomenon, that I call the financial centre bias, is inconsistent with a view of efficient primary equity markets where information is ubiquitous. It should be added to the phenomena of underpricing, and long-term underperformance, as an anomaly, worthy further consideration by finance practitioners, researchers and policy-makers. My empirical analysis shows that financial centre bias holds in an absolute majority of European countries, the USA and Japan. I explain how this phenomenon is likely to be underpinned by the following: tacit information flows, access to labour markets, corporate governance incentives, and cultural factors. In addition, the paper presents an exploratory analysis on why the degree of financial centre bias differs between countries, with results pointing to the significance of public policy and corporate governance.

The next section develops hypotheses on why provincial firms are less likely to go public. Section 3 introduces data and empirical methodology. Section 4 discusses empirical results and section 7 concludes with implications and speculations on the future geography of IPOs. 


\section{Why are provincial firms less likely to go public?}

There is extensive theoretical and empirical literature on why companies go public (for reviews see Bancel and Mittoo, 2008; Ritter and Welch, 2002; Röell, 1996), and why propensity of companies to go public differs between countries (Ritter, 2003), as well as industries (Brau and Fawcett, 2006). However, to my knowledge there is no systematic literature on why propensity to go public could depend on corporate location within a country. In this section, I propose four groups of factors, which I believe make provincial firms less likely to go and to be public. To be sure, these factors are bound to differ between regions, cities, and communities. Nevertheless, I will argue that the main distinction that affects the participation of firms in public stock markets is between provincial areas and financial centres. The latter are defined as cities that are concentrations of financial and other advanced business services. The term is relative as there could be regional, national, and international financial centres. This paper does not preclude a relative definition of financial centres, but it focuses on the national scale.

\section{Tacit information flows}

IPO is a multi-stage process of intensive exchange of information. First the company going public produces a prospectus. To this end it appoints an investment bank as the lead manager, which performs the due diligence investigations to produce information required to satisfy the appropriate regulatory authorities. The leading bank can also create a syndicate with other banks that will underwrite and/or market the issue to investors. Once the prospectus is ready, marketing of the issue to investors takes place. Senior managers of the issuer go on road-shows, giving presentations in places with large concentrations of investors, while investment bankers in the syndicate bring the issue to the attention of their client investors. The marketing stage generates information that is crucial for setting the price of the issue. The final phase of an IPO involves pricing and allocation of shares through one of three methods: fixed price, book building and auction. In the fixed price method, the share price is determined prior to collecting bids from investors. If the issue is oversubscribed, the remaining shares are paid for by the underwriting banks. If it is oversubscribed, shares are allocated according to predetermined rules. The book-building method starts with the investment bank inviting selected investors to participate and submit their indications of demand. Once the bank knows the demand curve for the issue, it determines the issue price and the allocation of shares to investors. While the final allocation may reflect the preferences of the issuer, the investment bank retains considerable discretion. IPO auctions, in contrast, involve pre-determined rules of pricing and allocation, which can be executed by a computer. Finally, after shares are allocated, the role of the investment banks often continues as they stabilise the share price, support liquidity for the shares, and provide analyst coverage of the company (Jenkinson and Ljungqvist, 2001).

From the description of the IPO process it is apparent that the central relationships in an IPO are those among issuers, investment banks, and investors. What is more, information exchanges in the process involve soft or tacit information, which is hard to communicate at a distance (Gertler, 2003). The investment bank has to be well informed about the prospects of the issuer and the likely investor demand. The issuer has an advantage over the bank with regard to information about its own prospects, 
but at a disadvantage when it comes to information about the market as a whole, valuation of other companies in the sector, and consequently the likely demand for its shares. As a result, the issuer needs to know the reputation of the bank, and has to trust that the bank will set the right issue price, neither too low (reducing the issuer's revenue from IPO) nor to high (ending in undersubscription). What helps an issuer in their relationship with investment banks is the issuer's own knowledge about likely investor demand. Investors on the other hand, need information about issuers to reduce their investment risk. Proximity to the investment bank and issuer may also help an investor obtain additional information and/or favourable treatment in the process of price-setting and allocation. In short, proximity helps information flows in an IPO, and is indispensible for establishing mutual trust between the issuer and the investment bank, central to the whole IPO process (Ellis et al. 1999; Corwin and Schultz, 2005).

\section{Figure 1. Key information flows in an IPO}

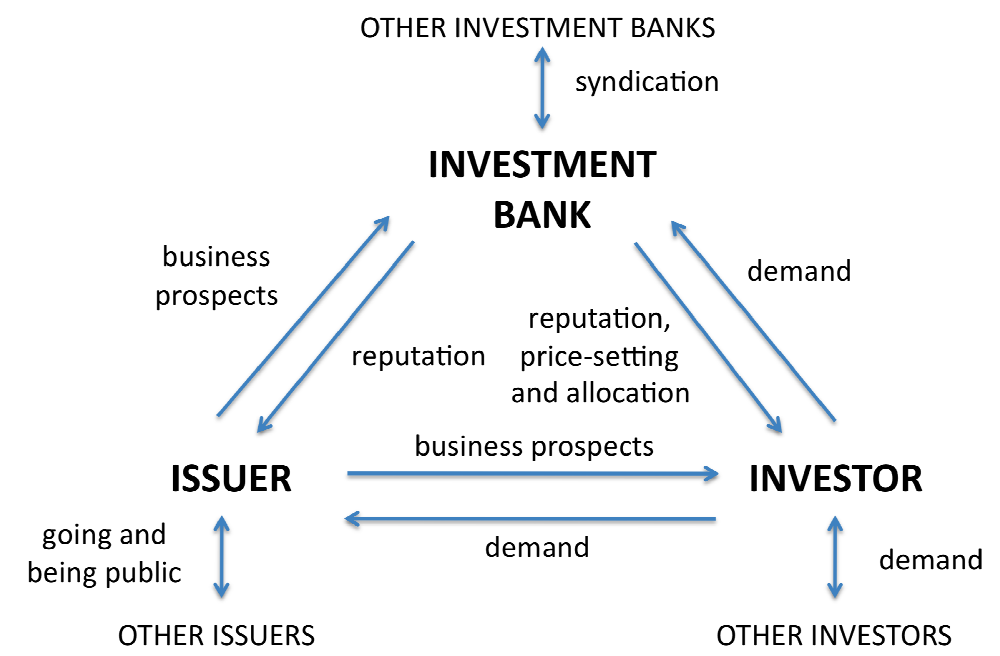

Figure 1 depicts the key information flows in an IPO, indicating that proximity is significant also within different groups of actors. Proximity among investment banks helps information flows needed to build and run a syndicate. Spatial concentration of investors helps them observe each other's interest in the issue. Finally, proximity of other companies that are already public or are going public helps the inexperienced issuer to assess the costs and benefits of an IPO, as well as to avoid mistakes and piggyback successful practices of their peers. What figure 1, for the sake of simplicity, does not show are other intermediaries involved in an IPO. It is typical of companies going public to appoint new lawyers and new auditors, usually ones that are more recognisable to public investors (Burton et al., 2004). Given the intensive flows of tacit information, proximity of an issuer to investment banks, investors, other issuers, and other specialised service providers makes the IPO process less costly. As Burton et al. (2006, pp. 689-90) summarise their empirical survey of IPOs in the UK "the time top management had to spend with advisers including bankers, brokers, lawyers and accountants was significant, and often resulted in some focus being taken off the business, so that the performance of company declined in short term". If interactions with IPO advisors are so costly, savings afforded by proximity can be important. 
There is another important aspect of tacit information flows between issuers and investors. According to the literature on 'local bias', investors proximate to the headquarters of the issuer, form a crucial set of informed investors and a pool liquidity for the issuer's shares. If an area has few potential investors and little capital that could be invested in equity, then firms from this area are likely to find it difficult to access public equity markets. This is exactly the reasoning behind the findings that rural firms in the US are less likely to go public, and when they are public, suffer from lower liquidity of their shares than urban firms (Loughran and Schultz, 2005 and 2006). The role of liquidity is also highlighted by Subrahmanyan and Titman (1999) who argue that "the net benefit from going public depends on the size of public markets - that is, the number of firms already trading publicly. The benefit from going public is greater in a large, liquid public market". Consequently they underscore path dependence in the development of public stock markets, with 'bad equilibria', in which many firms remain private, and 'good equilibria' in which most firms are publicly traded. While Subrahmanyan and Titman's theory is concerned with national stock markets, it is plausible that the positive externalities of many firms being or going public are not necessarily country-wide, they may be regional and local. Simplifying, within a country, financial centre may be in the state of 'good equilibrium', with provinces in general (or individual regions) in the state of 'bad equilibrium'.

Thus, tacit information flows are important for firms not only when they go public but also afterwards, when they are public. A public company needs continued relationship with investment banks (e.g. to conduct secondary public offerings or interact with stock analysts), investors, auditors and lawyers (to prepare reports required from public companies), and other specialised service providers. Put differently, tacit information flows required for going and being public imply benefits from the colocation of relevant actors. Consequently, the proportion of potential issuers that are public should be higher in financial centres than in provincial areas.

\section{Access to specialised labour markets}

Access to specialised labour markets is another element of localisation and agglomeration economies, which is important for firms going and being public. First, being close to investment banks, major investors and specialised service providers, implies staying close to a large pool of specialised highly skilled labour that these institutions require. There is however a direct impact as well, since a firm going public needs to employ new specialists, including: executives (particularly financial executives), non-executive directors, investor relations experts, and accountants skilled in financial reporting required from public companies (Burton et al, 2004 and 2006). Such specialists are most likely to be found in financial centres.

\section{Principal-agent problem and private benefits of control}

I now move to hypotheses related to corporate governance, which narrowly defined refers to relationships between corporate managers and shareholders, and broadly defined - relationships among all stakeholders of a company (Wójcik, 2009). The principal - agent problem is the central issue of corporate governance and occurs with the separation of ownership and control, i.e. when owners (principals) are different 
people than managers (agents). The problem is how to make managers act in the interest of owners.

In a typical private firm owners are identical with managers (e.g. a member of the family who owns the firm is the manager), are closely related to them (a trusted friend of the owners) or at least there are dominant owners in the firm who control the managers. As a result the interests of managers are aligned tightly with the interests of owners. IPO by nature involves the introduction of public (minority/small) investors into the ownership structure. As a result the interests of managers and owners diverge, and the former have incentives to extract private benefits of control (also called perquisite consumption) of pecuniary (e.g. diversion of corporate resources to other companies owned by managers or their families) and non-pecuniary (e.g. financing glamorous projects) character (Dyck and Zingales, 2004). To be more precise agency problems that arise with an IPO may take three forms. Minority shareholders can be exploited by (a) managers, (b) dominant owners, (c) managers and dominant owners. Exploitation by managers is a typical problem in Anglo-American corporate governance; by dominant owners in Japan and Continental Europe (La Porta et al., 1999; Shleifer and Vishny, 1997). One way or another, corporate governance theory posits that managers' (and/or dominant owners') incentives to maximise private benefits rather than firm value increase in the fraction of equity capital held by outside/small shareholders (Jenkinson and Ljungqvist, 2001).

The issue for this paper is whether the agency problem could differ between firms from financial centres and provinces. Recent research in corporate governance offers some clues. First, Landier, Nair and Wulf (2007) show that in the USA multi-branch firms that downsize their activities tend to close branches and lay off employees in remote locations before they downsize activities close to the headquarters. This local employee protection afforded by managers is significant only when the firm is headquartered in a less populated county. Interpretation offered is that close social interactions, more typical of smaller communities, increase managerial concern for employees and status in the community. Holmén and Högfeldt (2004), in turn, in a paper on Swedish corporate governance suggest that a relation-based environment like Scandinavia, where informal rules and social standing are important checks and balances, limits the dominant owners' incentives to myopically extract pecuniary benefits. Put differently, they claim that in Sweden social norms and informal institutions can protect minority owners from majority owners and managers.

Thus, Landier et al. seem to suggest that incentives to extract private non-pecuniary benefits of control are higher in the provinces (with more closely-knit, less anonymous communities), while Holmén and Högfeldt claim that incentives to extract private pecuniary benefits may be higher in large urban centres. My intuition is that on balance provincial firms face higher agency costs when they go public. An IPO, conducted outside of the province, in the financial centre, introduces investors that are not only small but also relatively remote. First, these investors (in contrast to local investors) will not participate in non-pecuniary benefits that managers (and dominant owners) may extract. Second, these investors have limited means to oversee whether managers in provincial companies are not colliding with local political and business elites to extract pecuniary benefits. If this speculation is correct, and the scope for and incentives for private benefits are larger in provincial companies, then public investors (particularly remote ones) will be less willing to buy shares in these 
companies. Lower demand for their shares would consequently lead to lower participation of provincial companies in public equity markets.

\section{Managerial entrenchment}

Being public implies increased pressure on senior management due to closer public scrutiny (Röell, 1996). As public companies are more transparent than private firms, performance of managers in public companies is more readily comparable. In addition, public companies may be subject to a market for corporate control, facing the threat of a hostile takeover. In general managerial entrenchment in a public company is smaller than in a private firm. The reduction in entrenchment as a result of going public, however, could have different ramifications for managers in provincial firms than for those in financial centres. If the manager of a provincial firm going or being public is unsuccessful, she/he faces the threat of losing a job and possibly reputation in a small labour market and generally smaller social environment. To get a new job and regain reputation the manager may need to relocate. Thus, the potential personal cost of going public may be greater for provincial managers than for those from financial centres. Arguably, the potential reward is greater as well, as it is easier for a provincial manager to become a local business celebrity solely on the basis of a successful IPO. While the expected value of net benefits from going public may be similar in the end, psychology and behavioural economics suggest that when faced with two options with same expected value, people tend to chose one with lower downside risk (Kahneman and Tversky, 1979). Thus, even if financial centre-based and provincial managers have the same level of risk aversion, the latter may be less willing to take their companies public.

\section{Cultural factors}

The preceding section suggests that an extra dose of downside risk faced by provincial managers may lead to a lower willingness to go public. What may lower this willingness further is potentially stronger risk aversion in the provinces in relation to the financial centre. This is not unlikely given that financial centres are large cities with a large financial sector but mostly with large creative industries as well (Florida 2003, Scott, 2000). Financial centres may be homes to more risk prone people.

What matters in addition to risk culture is equity culture, the extent to which individuals are accustomed to investing in equity and firms accustomed to using equity for financing. It is well established that equity culture differs between countries (Morck, 2005), but my proposition is that it also varies within countries, and that in particular it is likely to be stronger in financial centres than in the provinces.

The final important cultural factor involves corporate culture. Empirical research describes IPOs in the UK as a 'culture shock' for companies (Burton et al. 2004, p.358). Marchicio and Ravasi (2008) claim that IPOs in Italy require a change in 'corporate mentality'. They also argue that going public involves a transformation of the social network through which the company collects and deploys resources and capabilities (p.7). For a company it is a step based on economic incentives and quantifiable costs and benefits, but also a social and cultural transition that managers and owners must be willing to undertake. Asking executives of provincial firms around Europe why they do not go public, the author of this paper often heard the 
answer that financial centre is the 'world of high finance' and they do not feel they belong there.

\section{Methodology and data}

In order to test whether provincial companies are less likely to participate in public stock markets than companies from financial centres, we need to define participation in the public stock market, as well as identify the population of companies that could potentially participate in these markets. The operational definition of a financial centre is also required, but this will be discussed at the start of the next section.

In this paper, companies participating in the stock markets are defined as all companies that are publicly listed or at least publicly quoted and traded. A detailed list of each country's market segments covered in the paper is presented in appendix 1. The paper covers all alternative, smaller company, and technology focused segments of stock markets, and this generous coverage is consistent with the paper's objective to evaluate the geographical bias of the public stock market in its entirety. Companies are considered stock market traded, if they are traded on any stock market in the world, not necessarily their home country market.

What broader population of companies in the underlying economy, should we compare the set of stock market issuers to? It is not possible to consider all enterprises existing in an economy due to the difficulty of obtaining internationally comparable data. Such an approach would also fail to recognise that companies participating in stock markets are relatively large, mainly as a result of fixed costs of stock market participation such as reporting costs as well as initial and ongoing listing fees (Pagano et al. 1998). For this reason this paper will compare the set of stock market companies to all companies with turnover in excess of $€ 50 \mathrm{~m}$, which is the threshold used officially in the European Union to distinguish between medium and large companies. In addition very large companies are defined as those with turnover in excess of $€ 200 \mathrm{~m}$.

The following measures of financial centre (FC) bias are proposed.

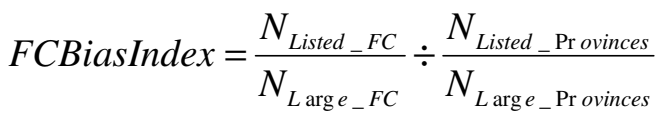

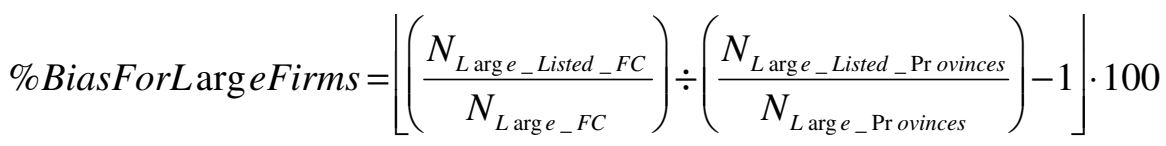

$$
\begin{aligned}
& \% \text { BiasForVeryLargeFirms }=\left\lfloor\left(\frac{N_{V L \text { arge_Listed_FC }}}{N_{V L_{\text {arge } e_{-} F C}}}\right) \div\left(\frac{N_{V L \text { arge_Listed_Pr ovinces }}}{N_{V L \text { arge__Pr } \text { ovinces }_{1}}}\right)-1\right] \cdot 100
\end{aligned}
$$

The FC Bias Index captures all listed companies, including those with turnover below $€ 50 \mathrm{~m}$, and relates them to the number of large companies in the underlying economy. The other two measures exclude listed companies with turnover below $€ 50 \mathrm{~m}$, but are more straightforward to interpret. The first shows by what percentage large companies 
headquartered in the financial centre are more likely to be publicly traded than large companies not headquartered in the financial centre. The second shows by what percentage very large companies headquartered in the financial centre are more likely to be publicly traded than very large companies not headquartered in the financial centre.

To be sure, what counts as a publicly traded company in one country, would not necessarily be recorded as such in another country. Listing rules differ between countries and between stock exchanges. Lenient listing rules can result in high and strict rules in low numbers of recorded issuers. This is however not a major problem for this paper, which does not focus on the percentages of companies that are publicly traded, but rather on the ratios of such percentages between financial centres and provincial areas. In other words, the objective is to evaluate the geographical bias of the public stock market, irrespective of the definition of the public stock market in a given country.

\section{Data}

Data for the paper were obtained from the ORBIS database, provided by Bureau Van Dijk Electronic Publishing (BDEP). They were harvested by the author in October 2006, but the database was last updated by the BDEP at the end of September 2006. The data were obtained for all 27 European Union member states (including Bulgaria and Romania), Iceland, Norway, Switzerland, as well as Japan and the USA, giving a total of 32 countries. Data on the numbers of publicly traded companies are valid for the end of September 2006. The data were compared with those available from such sources as the World Federation of Exchanges, the Federation of European Stock Exchanges, and websites of individual stock exchanges. No major discrepancies were detected.

Data on the number of companies operating in the underlying economies were collected by filtering companies with turnover in excess of $€ 50 \mathrm{~m}$ and $€ 200 \mathrm{~m}$, respectively, out of all companies included in ORBIS. Turnover figures were based on consolidated financial statements, if available (unconsolidated otherwise), for the last financial year, for which they were available (mostly 2005). The thresholds of $€ 50 \mathrm{~m}$ and $€ 200 \mathrm{~m}$ were adjusted to the country price level, using Eurostat-OECD comparative price levels for 2005 , based on the price of a representative basket of consumer goods and services (for details see OECD 2006). The comparative price level for the 30 OECD countries combined is set at 1; indices for individual sample countries in 2005 ranged from 0.40 for Bulgaria to 1.46 for Iceland. The adjusted turnover thresholds were calculated by multiplying $€ 50 \mathrm{~m}$ and $€ 200 \mathrm{~m}$ respectively by a country's comparative price level, and for non-Eurozone countries were translated into domestic currency using the respective Euro exchange rates as at the end of September 2006.

An important issue is whether the ORBIS database captures reliable numbers of all large companies operating in the sample countries. Unfortunately, it is not possible to compare the ORBIS data with those from the Eurostat's New Cronos database, since the latter defines large companies on the basis of the number of employees, not turnover, and the data are often out-of-date and available only for few countries. The use of multiple sources of corporate data by the BVDEP, resulting in impressively high numbers of companies included in ORBIS serves as an important source of 
assurance. While the numbers of publicly traded companies for European sample countries, Japan, and the USA were 8,646, 3,858, and 8,861 respectively; and the numbers of large companies were 59,300, 12,338, and 35,407; the numbers of all companies covered by ORBIS were over 10 million, over 1 million, and nearly 2 million, respectively. Thus, large companies represent less than $1 \%$ of all companies in the ORBIS database. Given that the likelihood of the BVDEP having data on a company grows with the size of the company, the coverage of large companies in the paper should be reliable.

\section{Empirical evidence on the financial centre bias}

This section presents results on the extent to which stock markets are biased towards companies from financial centres. For six European countries without an obvious single financial centre, the ratios were calculated for two or more major financial centres combined: Berlin, Düsseldorf, Frankfurt am Main, and Munich in Germany; Milan, Rome, and Turin in Italy; Amsterdam and Rotterdam in the Netherlands; Lisbon and Porto in Portugal; Barcelona and Madrid in Spain; Basel, Geneva, and Zürich in Switzerland. As companies are assigned to places where they are headquartered, it is important to carefully delimit the spatial scope of financial centres. The general objective was to treat financial centres as agglomerations, including adjacent urban areas, even if from an administrative point of view they constitute separate cities or townships. For example, the financial centre of France was defined as Ile de France, and that of the USA as the Metropolitan Statistical Area (MSA) of New York - Northern New Jersey - Long Island. Considering the idiosyncratic character of spatial and administrative structures of large cities, details of the financial centres covered, including their spatial scope, are presented in appendix 2 .

As table 1 shows the FC Bias Index is greater than 1 in 22 out of 32 countries. This means that for a majority of countries as well as for EU 15 and Europe as a whole, the ratio of issuers to potential issuers is larger in the financial centres than in the rest of the country. This is confirmed when we analyse the percentage bias for large companies. In 21 countries a large company is more likely to be listed if it is headquartered in the financial centre. In EU 15 a large company is $42 \%$ more likely to be listed if it comes from the financial centre. This is more than in the USA but less than in Japan, where the percentage bias for large companies is $15 \%$ and $63 \%$ respectively. The financial centre bias prevails in each of the five largest economies of the EU - France, Germany, Italy, Spain and the UK.

If we extend analysis to very large companies, the financial centre bias holds for 19 countries out of 29 for which data are available. In EU 15 a very large company is $32 \%$ more likely to be listed if it comes from the financial centre, in Japan 17\% more likely to be listed. In the USA, a very large company from New York City is actually $4 \%$ less likely to be listed than a very large company from the rest of the country. The relationship between results for large companies and those for very large companies is significant. The financial centre bias is stronger for large companies than it is for very large companies. This is the case for 19 countries, including the USA and Japan, as well as the EU15 as a whole. Therefore it seems that the factors described as inhibiting provincial companies' participation in public stock markets have a stronger 
impact on relatively small companies. Very large companies may find it easier to participate in the networks of information exchange with intermediaries and investors in financial centres; easier to access specialised labour markets; and it may be a more pressing need for them to obtain external equity capital in spite of potential entrenchment and private benefits of control.

There is one methodological issue, which further reinforces the findings on the existence of the financial centre bias. Recall that potential issuers in each country are identified as companies exceeding $€ 50 \mathrm{~m}$ in turnover. The threshold of $€ 50 \mathrm{~m}$ is adjusted to the country price level, but the difference in the level of prices between financial centres and the rest of the country is not accounted for. If higher prices in financial centres were accounted for, relatively more companies would be counted as large in the provinces, resulting in higher values of the FC Bias Index and higher percentage bias for large and very large companies.

\section{Is financial centre bias driven by sectoral bias?}

Does the geographical bias exist because financial centres are concentrations of highly represented sectors, such as financial services or high-technology firms? Answering the question requires data on sector affiliation as well as location for each company. Such data are available only for the UK. With London as the hub of global finance, and of the British venture capital industry, the UK is a very useful case. Given that the FC bias in the UK is lower than the European average, it may be particularly sensitive to sectoral bias.

In order to test the relationship between geographical and sectoral stock market representativeness for the UK the FC Bias Index was calculated separately for each of the 56 NACE sectors (by Eurostat, as amended in 2001, also known as Rev.1.1 NACE codes), for which there are any publicly traded UK firms. A company is considered as located in London, if it is headquartered in Greater London. Results show that the FC Bias Index is higher than one for 38 , i.e. approx. $68 \%$ of sectors. Thus, in an absolute majority of sectors, companies from London are more likely to be publicly traded than provincial firms. For financial intermediation the FC Bias Index is 1.01. While London hosts approx. two thirds of the UK publicly traded financial intermediation firms, it also hosts approx. two thirds of all large financial intermediation firms that exist in the UK. Within high-technology manufacturing, the FC Bias Index is above one for manufacturing of radio, television, and communication equipment (1.37), as well as medical, precision, and optical instruments (1.19), but below one for office machinery and computers (0.59). Within high-technology knowledge intensive services, the index is above one for post and telecommunications (1.39), but below one for computer activities (0.97), and research and development (0.77). Considering large sectors, with large absolute numbers of firms, the highest levels of London advantage are found in the manufacturing of chemicals and the manufacturing of machinery and equipment, with the FC Bias Index values of 2.38 and 3.13, respectively.

To summarise, in the UK the financial centre bias prevails in an absolute majority of sectors. Its existence is not determined by sectors concentrated in London having an advantage over sectors concentrated in the provinces in terms of their stock market participation. 


\section{Why financial centre bias differs between countries?}

The empirical evidence shows that the degree of financial centre bias differs greatly between countries. This section presents exploratory analysis of the potential reasons behind these differences.

If financial centre bias is affected by proximity of potential issuers to investment banks and other specialised intermediaries, then the bias could be greater in countries where the average distance between potential issuers and the financial centre (or centres) is greater. Simplifying, we might expect a larger financial centre bias in larger countries. To test this hypothesis Spearman's rank correlation coefficient was calculated between the measures of financial centre bias and the total area of a country. Table 2 presents results, separately for the samples of all 32, 22 nontransition, and 10 transition countries, and shows no relationship between country size and financial centre bias. There are small countries such as Luxembourg or Belgium with strong large financial centre bias, and large countries such as Sweden or Finland with weak bias. This suggests that the financial centre bias may have more to do with social and cultural proximity of issuers to financial centres and specialised intermediaries than with physical distance.

The level of financial centre bias could also be related to the general level of stock market development. Companies from the financial centre may be the first ones to get listed, but as stock market develops it could penetrate other parts of the country. I test this hypothesis with two measures of stock market development: the ratio of market capitalisation of domestic companies to GDP (MC/GDP); and the percentage of large companies that are publicly traded (PL/AL). Results lend some support for the hypothesis. There is indeed a negative correlation between FC bias and the percentage of large companies that are publicly traded, particularly in non-transition countries. Thus, diffusion of stock market engagement from the financial centre to the rest of the country may indeed take place.

The third hypothesis, on the relationship between the FC bias and corporate governance, stems from my previous research on Germany demonstrating that the institutional concentration of ownership in companies is higher in regions that are relatively closed to investors from outside the region (Wójcik, 2003). For example, in Hesse and Hamburg in contrast to Baden Württemberg, fewer public companies have dominant owners and there are more investors from outside the region (Wójcik, 2002). Thus, concentrated ownership tends to coincide with local ownership. This suggests a potential relationship between corporate governance and geographical bias in primary equity markets. Countries with higher institutional concentration of corporate ownership may rely on more locally/regionally based financial interactions and have financial centres that are more 'closed' to provincial firms than countries with relatively open ownership structures. In other words, institutional closeness/openness of a corporate governance regime may coincide with its geographical closeness/openness. To test the relationship between corporate governance and the FC bias I use data on the percentage of publicly traded companies that are widely held $(\mathrm{PWH} / \mathrm{P})$, i.e. with no shareholders owning more than $25 \%$ of shares directly or indirectly. For non-transition countries, there is indeed a negative and significant correlation between FC bias and the percentage of widely held 
companies. To be sure, the relationship between corporate governance and the FC bias is likely to be a two-way relationship. Since IPOs dilute corporate ownership, the FC bias would reinforce the difference between relatively high ownership concentration in the provinces and low concentration in the financial centre.

The power of explaining the FC Bias with the level of stock market development and corporate governance is limited due to the most striking feature of the results in table 1. Namely, in transition countries the FC Bias is non-existent or very weak, although these countries have underdeveloped stock markets, particularly in terms of MC/GDP, and closed ownership structures in comparison with Western Europe or the USA. In my view, this apparent anomaly can be explained with the role of privatisation as a major route of firms entering public stock markets in transition countries, as well as public policy aimed at geographically inclusive markets. First, in transition countries the share of companies that entered public equity market via privatisation of formerly state-owned enterprises is higher than in 'mature' market economies (Perotti and Oijen, 2001). As a result the geography of IPOs and public equity markets in transition countries has been shaped significantly by the state's priorities of privatisation and raising revenue from it, which have subdued the barriers and disincentives faced by provincial firms and related to tacit information flows, access to specialised labour markets, corporate governance, and culture. In addition, stock exchanges in these countries were developed and at least until recently owned by the governments as not-for-profit organisations, and tools of capital market development policy, with one of its objectives being to reach potential issuers in different parts of the country (Wójcik, 2007).

The list of factors that could explain the cross-country variation of the FC Bias could be extended to include the level of competition among intermediaries (mainly investment banks) that assist firms going public, rules of stock exchange listing prevailing in a country, or tax systems encouraging or discouraging firms from going public. Due to the difficulty of collecting and quantifying data on such factors, as well as exploratory character of the analysis in this section, I leave these issues to future papers.

\section{Conclusion and implications: towards disintermediated IPOs?}

Research on IPOs has been focused on two anomalies: underpricing and long-term underperformance. There is however, another anomaly that has escaped the attention of financial economists - the financial centre bias, the fact that firms from financial centres are more likely to go public than their provincial counterparts. This paper assembles theoretical reasons for and empirical evidence on the financial centre bias. The primary reasons of the bias are likely to be the benefits of issuers' proximity to IPO intermediaries and specialised labour markets. Second, there are corporate governance incentives that could lower both the supply and the demand for provincial IPOs. In addition, the differences between financial centres and provinces in terms of risk, equity, and corporate culture may also make provincial firms' IPOs less likely. Empirical analysis covering 32 countries, including the whole European Union, as well as the USA and Japan, shows that even according to conservative measures, the financial centre bias is common, and is particularly strong in countries with underdeveloped stock markets and closed corporate governance regimes. However, 
the financial centre bias is still present in countries with the most developed stock markets and most open corporate governance, such as the UK and the USA. In fact, in almost all countries where there is no financial centre bias, this is most likely due to state intervention, in particular the role of privatisations in taking companies public, and capital market development policy.

In the age of internet, it may sound strange to talk about provincial firms or the role of proximity to financial centres. After all, we have seen successful internet IPOs, such as Google's, whereby collection of buy orders, pricing and allocation of shares were executed through computer networks. Does not it imply the arrival of disintermediated IPOs that would make the financial centre bias history? Most probably not. First, internet auctions have certain disadvantages, which may explain why they are the least popular, while heavily intermediated book-building remains the most popular IPO method. In book-building, discretion afforded to bankers and issuers makes it easier to reward investors undertaking costly information seeking and research and thus contributing to price discovery, while fully disintermediated auctions face problems of free-riding, with investors waiting for others to undertake such activities (Jenskinson and Ljungqvist, 2001). A likely development in the future are hybrid IPO methods, with auctions encouraging the broad participation of retail investors, but at the same time retaining a significant degree of intervention and discretion on the side of investment banks and issuers. Finally, even if IPOs were to be fully disintermediated, the financial centre bias could still remain due to the geography of corporate governance, labour markets, and cultural factors.

This paper opens new research avenues in financial economics and economic geography. Financial economists should be reminded that in addition to the geography of national and international financial systems, there is also an important geography at the sub-national scale of analysis. If we simplify this geography to the distinction between financial centres and provinces, we may expect more arm's length relationships and stock market based financing in financial centres, with more relationship-based finance and higher reliability on bank credit in the provinces. Of course, for geographers this distinction should not suffice. Provincial regions, cities and communities differ in respect of their financial systems. Hence the need for more research on how public stock market participation of firms, but also investors, differs within countries.

\section{Bibliography:}

Bancel, F. and Mittoo, U. 2008. Why European firms go public? Working Paper available on www.ssrn.com

Brau, J. and Fawcett, S. 2006. Initial public offerings: an analysis of theory and practice, Journal of Finance, vol. 61, pp. 399-436

Burton, B., Helliar, C., and Power, D. 2006. Practitioners' perspectives on the IPO process and the perils of flotation, The European Journal of Finance, vol. 12, pp. 671-92

Burton, B., Helliar, C., and Power, D., 2004, The role of corporate governance in the IPO process: a note, Corporate Governance: An International Review, vol. 12, pp. 353-60

Clark, G. L. and Wójcik, D. 2007. The Geography of Finance: Corporate Governance in the Global Marketplace, Oxford University Press

Corbridge, S., Thrift, N., and Martin, R. (eds), 1994, Money, Power and Space, Oxford, Blackwell

Corwin, S. and Schultz, P. 2005. The role of IPO underwriting syndicates: pricing, information production, and underwriter competition, Journal of Finance, vol. 60, pp. 443-486

Dyck, A. and Zingales, L. 2004. Private benefits of control: an international comparison, Journal of Finance, vol. 59, pp. 537-600 
Ellis, K., Michaely, R., and O'Hara, M. 1999. A guide to the initial public offering process, Corporate Finance Review, vol. 3, pp. 14-18

Florida, R. 2003. The Rise of the Creative Class, Basic Books

Gertler, M. 2003. Tacit knowledge and the economic geography of context, or the undefinable tacitness of being (there), Journal of Economic Geography, vol. 3, pp. 75-100

Holmén, M. and Högfeldt, P. 2004. A law and finance analysis of initial public offerings, Journal of Financial Intermediation, vol. 13, pp. 324-58

Jenkinson, T. and Ljungqvist, A. 2001. Going Public: The Theory and Evidence on How Companies Raise Equity Finance, Oxford University Press

Kahneman, D. and Tversky, A. 1979. Prospect theory: an analysis of decision under risk, Econometrica, 47, pp. 263-291

Klagge, B. and Martin, R. 2005. Decentralised versus centralised financial systems: is there a case for local capital markets?, Journal of Economic Geography, vol. 5, pp. 387-422

La Porta, R. and Vishny, R. 1999. Corporate ownership around the world, Journal of Finance, vol. 54, pp. 471-518

Landier, A., Nair, V., and Wulf, J. 2007. Trade-offs in staying close: corporate decision-making and geographic dispersion, Review of Financial Studies, vol. 20, no. 5

Leyshon, A. and Thrift N. 1997. Money/Space. Geographies of Monetary Transformation, London, Routledge

Loughran, T. and Schultz, P. 2006. Asymmetric information, firm location, and equity issuance, Working Paper, University of Notre Dame, available at http://leedsfaculty.colorado.edu/yungc/Seminar\%20Papers/location.pdf

Loughran, T. and Schultz, P. 2005 Liquidity: Urban versus Rural Firms, Journal of Financial Economics, vol. 78, pp. 341-74

Marchisio, G. and Ravasi, D. 2008. Family firms and the decision to go public: a study of Italian IPOs. Available on www.ssrn.com

Martin, R. (ed.) 1999. Money and the Space Economy, Chichester, J Wiley \& Sons

Morck, R. (ed.) 2005. A History of Corporate Governance Around the World, The University of Chicago Press

OECD 2006 Purchasing power parities, Report available at www.oecd.org/std/ppp.

Pagano. M., Panetta, F., and Zingales, L. 1998. Why do companies go public? An empirical analysis, Journal of Finance, vol. 53, pp. 27-64

Perotti, E.C. and Oijen van, P. 2001. Privatization, market development and political risk in emerging economies, Journal of international Money and Finance, vol. 20, pp. 43-69

Ritter, J. 2003. Differences between European and American IPO markets, European Financial Management, vol. 9, pp. 421-34

Ritter, J., and Welch, I. 2002. A review of IPO activity, pricing, and allocations, Journal of Finance, vol. 57, pp. 1795-1828

Röell, A. 1996. The decision to go public: an overview, European Economic Review, vol. 40, pp. 1071-81

Scott, A. 2000. The Cultural Economy of Cities, London, Sage

Shleifer, A. and Vishny, R. 1997. A survey of corporate governance, Journal of Financial Economics, vol. 52, pp. 737-83.

Subrahmanyam, A. and Titman, S. 1999. The going-public decision and the development of financial markets, Journal of Finance, vol. 54, pp. 1045-82

Wójcik, D. 2009. Corporate governance. In, Thrift, N., Kitchin, R. (eds.) International Encyclopaedia of Human Geography, Amsterdam, Elsevier

Wójcik, D. 2008. The role of proximity in secondary equity markets, Working Paper available on www.ssrn.com

Wójcik, D. 2007. Geography and future of stock exchanges: between real and virtual space, Growth and Change, vol. 38, pp. 200-223

Wójcik, D. 2003. Change in the German model of corporate governance: evidence from blockholdings 1997 - 2001, Environment and Planning A, vol. 35, pp. 1431-1458

Wójcik, D. 2002. The Länder are the building blocks of the German capital market, Regional Studies, vol. 36, pp. 877-895 


\section{Table 1. Financial centre bias}

The FC Bias Index is calculated by dividing the ratio of the number of publicly traded companies to the number of companies with turnover in excess of $€ 50 \mathrm{~m}$ in the financial centre of the country, by the equivalent ratio for the rest of the country. \% bias for large firms shows by what percentage companies with turnover in excess of $€ 50 \mathrm{~m}$ headquartered in the financial centre are more likely to be publicly traded than companies not headquartered in the financial centre. \% bias for very large firms does the same for companies with turnover in excess of $€ 200 \mathrm{~m}$. For six European countries without an obvious single financial centre, the ratios were calculated for two, three or four major financial centres combined. Figures for EU 15, EU Transition 10, and Europe were arrived at by adding the respective numbers of companies, and calculating indices and percentages on the basis of the resulting totals, not by averaging figures for individual countries. Details of the financial centres covered, including their spatial scope, are presented in appendix 2. MSA - Metropolitan Statistical Area. In Estonia and Malta there are no very large companies headquartered in the provinces, so the figure for \% bias for very large firms is not available. In Iceland there are neither large nor very large companies headquartered in the provinces, so the figure for \% bias for large and very large firms is not available. Source: Author's calculations based on data from BDEP and OECD

\begin{tabular}{|c|c|c|c|}
\hline Country - financial centre (-s) & $\begin{array}{l}\text { FC Bias } \\
\text { Index }\end{array}$ & $\begin{array}{l}\% \text { bias for } \\
\text { large firms }\end{array}$ & $\begin{array}{l}\% \text { bias for } \\
\text { very large } \\
\text { firms }\end{array}$ \\
\hline Austria - Vienna & 3.22 & 86 & 79 \\
\hline Belgium - Brussels & 2.37 & 124 & 133 \\
\hline Bulgaria - Sofia & 0.10 & -89 & -50 \\
\hline Cyprus - Nicosia & 2.35 & -12 & 33 \\
\hline Czech Republic - Prague & 1.04 & 15 & 33 \\
\hline Denmark - Copenhagen & 1.88 & 59 & 57 \\
\hline Estonia - Tallin & 1.62 & 85 & na \\
\hline Finland - Helsinki & 1.15 & 0 & 22 \\
\hline France - Paris & 1.70 & 86 & 60 \\
\hline Germany - 4 centres & 2.19 & 68 & 27 \\
\hline Greece - Athens & 1.19 & -16 & -39 \\
\hline Hungary - Budapest & 0.60 & -73 & -86 \\
\hline Iceland - Reykjavik & 0.68 & na & na \\
\hline Ireland - Dublin & 1.59 & -12 & -17 \\
\hline Italy - 3 centres & 1.74 & 54 & 13 \\
\hline Latvia - Riga & 0.29 & -71 & -71 \\
\hline Lithuania - Vilnius & 0.33 & -46 & -60 \\
\hline Luxembourg - Luxembourg & 5.55 & 232 & 90 \\
\hline Malta - Valletta & 1.78 & 100 & na \\
\hline Netherlands - 2 centres & 2.03 & 67 & 7 \\
\hline Norway - Oslo & 1.21 & 11 & 45 \\
\hline Poland - Warsaw & 1.00 & 14 & 25 \\
\hline Portugal - 2 centres & 1.76 & 160 & 151 \\
\hline Romania - Bucharest & 0.42 & -46 & -87 \\
\hline Slovakia - Bratislava & 0.60 & -49 & -75 \\
\hline Slovenia - Ljubljana & 0.77 & 1 & 10 \\
\hline Spain - 2 centres & 2.36 & 49 & 64 \\
\hline Sweden - Stockholm & 1.43 & 23 & 30 \\
\hline Switzerland - 3 centres & 0.71 & 7 & -6 \\
\hline UK - London & 1.82 & 26 & 11 \\
\hline EU 15 - all centres & 1.76 & 42 & 32 \\
\hline EU Transition 10 - all centres & 0.66 & -20 & -19 \\
\hline Europe - all centres & 1.50 & 34 & 26 \\
\hline Japan - Tokyo & 1.67 & 63 & 17 \\
\hline USA - New York MSA & 1.22 & 15 & -4 \\
\hline
\end{tabular}


Table 2. Financial centre bias vs. country size, stock market development and corporate governance

The table reports Spearman's rank correlation coefficients between the measures of the financial centre bias and: the total area of a country (Area); the percentage of publicly traded firms among all firms with turnover in excess of $€ 50 \mathrm{~m}$ (PL/AL); the ratio of domestic market capitalisation to GDP (MC/GDP); and the percentage of publicly traded companies that are widely held, i.e. have no shareholders owning more than $25 \%$ of shares directly or indirectly (PWH/P). Transition countries are: Bulgaria, Czech Republic, Estonia, Hungary, Latvia, Lithuania, Poland, Romania, Slovakia, and Slovenia. Non-transition are all other countries. Coefficients are significant at $10 \%$ $\left({ }^{\star}\right), 5 \%\left(^{* \star}\right)$ or $1 \%\left(^{* \star \star}\right)$. Source: Author's calculations based on data from BDEP, OECD, World Bank, and the World Federation of Exchanges.

\begin{tabular}{|c|c|c|c|c|c|c|c|c|}
\hline Index & Countries included & Area & $\mathrm{PL} / \mathrm{AL}$ & & MC/GDP & & $\mathrm{PWH} / \mathrm{P}$ & \\
\hline \multirow{3}{*}{$\begin{array}{l}\text { FC Bias } \\
\text { Index }\end{array}$} & All & -0.098 & -0.305 & * & 0.447 & $* * *$ & 0.211 & \\
\hline & Non-transition & -0.351 & -0.484 & ** & -0.356 & & -0.448 & ** \\
\hline & Transition & -0.244 & -0.476 & & 0.649 & ** & 0.103 & \\
\hline \multirow{3}{*}{$\begin{array}{l}\% \text { bias for } \\
\text { large firms }\end{array}$} & All & -0.059 & -0.304 & * & 0.489 & $* * *$ & 0.214 & \\
\hline & Non-transition & -0.205 & -0.422 & * & -0.063 & & -0.346 & \\
\hline & Transition & -0.241 & -0.262 & & 0.561 & * & 0.006 & \\
\hline \multirow{3}{*}{$\begin{array}{l}\% \text { bias for } \\
\text { very large } \\
\text { firms }\end{array}$} & All & 0.043 & -0.239 & & 0.382 & ** & 0.213 & \\
\hline & Non-transition & -0.123 & -0.288 & & -0.299 & & -0.432 & * \\
\hline & Transition & -0.025 & 0.050 & & 0.427 & & 0.467 & \\
\hline
\end{tabular}


Appendix 1. Publicly traded companies by country at the end of September 2006

Note: For each country the appendix gives the total number of publicly traded companies, and a description of stock market segments included. The data were obtained from ORBIS by the BVDEP, and their consistency was tested by comparison to data from the World Federation of Exchanges, the Federation of European Stock Exchanges, and the websites of individual stock exchanges. In addition to the domestic segments stated, for each country the numbers include companies that are publicly traded only on a foreign exchange (for example the Irish companies traded on the Alternative Investment Market (AIM) of the London Stock Exchange, but not traded on the Irish Stock Exchange).

\begin{tabular}{|c|c|c|}
\hline Austria & 109 & Prime and Standard segment of the Wiener Börse \\
\hline Belgium & 159 & Eurolist and Marché Libre of the Euronext Brussels \\
\hline Bulgaria & 341 & $\begin{array}{l}\text { All companies listed on the Official and Unofficial Market of the } \\
\text { Bulgarian Stock Exchange }\end{array}$ \\
\hline Cyprus & 142 & All companies listed on the Cyprus Stock Exchange \\
\hline Czech Republic & 37 & All companies listed on the Prague Stock Exchange \\
\hline Denmark & 178 & $\begin{array}{l}\text { All companies listed on the OMX Copenhagen and the First North } \\
\text { Exchange }\end{array}$ \\
\hline Estonia & 16 & All companies listed on the OMX Tallin \\
\hline Finland & 134 & All companies listed on OMX Helsinki. \\
\hline France & 946 & Eurolist, Alternext, and Marché Libre of the Euronext Paris \\
\hline Germany & 1014 & $\begin{array}{l}\text { Official Market and the Open Market (Freiverkehr i.e. the } \\
\text { Regulated Unofficial market) of the Deutsche Börse. }\end{array}$ \\
\hline Greece & 336 & $\begin{array}{l}\text { Big cap, mid and small cap, special financial character, and under } \\
\text { surveillance companies at the Athens Stock Echange, but not } \\
\text { suspended listed companies. }\end{array}$ \\
\hline Hungary & 37 & $\begin{array}{l}\text { All companies with equities category A or B traded on the } \\
\text { Budapest Stock Exchange }\end{array}$ \\
\hline Iceland & 22 & All companies listed on the Iceland Stock Exchange \\
\hline Ireland & 114 & $\begin{array}{l}\text { The Official List and the Irish Enterprise Exchange (IEX) of the } \\
\text { Irish Stock Exchange. }\end{array}$ \\
\hline Italy & 292 & $\begin{array}{l}\text { All segments of the Borsa Italiana i.e. Blue Chip, Star, Standard, } \\
\text { and Mercato Expandi }\end{array}$ \\
\hline Latvia & 39 & All companies listed on the OMX Riga \\
\hline Lithuania & 43 & All companies listed on the OMX Vilnius \\
\hline Luxembourg & 49 & All companies listed on the Luxembourg Stock Exchange \\
\hline Malta & 11 & $\begin{array}{l}\text { All companies listed on the official list of the Malta Stock } \\
\text { Exchange }\end{array}$ \\
\hline Netherlands & 224 & All companies listed at Euronext Amsterdam \\
\hline Norway & 277 & $\begin{array}{l}\text { All segments of the Oslo Stock Exchange i.e. OBX, OB Match, OB } \\
\text { Standard, and OB New. }\end{array}$ \\
\hline Poland & 241 & $\begin{array}{l}\text { All companies listed on the Main and the Parallel Market of the } \\
\text { Warsaw Stock Exchange }\end{array}$ \\
\hline Portugal & 73 & All companies listed on the Euronext Lisbon \\
\hline Romania & 69 & All companies listed on the Bucharest Stock Exchange \\
\hline Slovakia & 251 & All companies with shares traded on the Bratislava Stock Exchange \\
\hline Slovenia & 81 & $\begin{array}{l}\text { All companies on the Official and Semi-Official Market of the } \\
\text { Ljubljana Stock Exchange }\end{array}$ \\
\hline Spain & 198 & $\begin{array}{l}\text { Companies traded on the Continuous Market and the Floor of the } \\
\text { Bolsas y Mercados Españoles (BME-X). SICAVs and SIMs are not } \\
\text { included. }\end{array}$ \\
\hline Sweden & 395 & $\begin{array}{l}\text { All companies listed on the OMX Stockholm, the Nordic Growth } \\
\text { Market, and the First North Exchange }\end{array}$ \\
\hline
\end{tabular}




\begin{tabular}{|l|c|l|}
\hline Switzerland & 274 & $\begin{array}{l}\text { Main Market, Local Caps, Real Estate Companies and Investment } \\
\text { Companies of the SWX Swiss Exchange. }\end{array}$ \\
\hline UK & 2542 & $\begin{array}{l}\text { All companies listed on the London Stock Exchange, including the } \\
\text { AIM }\end{array}$ \\
\hline Japan & 3858 & $\begin{array}{l}\text { All companies traded on the Tokyo Stock Exchange, the JASDAQ, } \\
\text { the Nagoya SE, the Osaka Securities Exchange, the Sapporo Stock } \\
\text { Exchange, and the OTC Japan }\end{array}$ \\
\hline USA & 8861 & $\begin{array}{l}\text { The New York Stock Exchange, the NASDAQ National Market, } \\
\text { the NASDAQ Bulletin Board, the American Stock Exchange, and } \\
\text { other OTC markets }\end{array}$ \\
\hline
\end{tabular}




\section{Appendix 2. Financial centres and their spatial scope}

\begin{tabular}{|c|c|c|}
\hline Austria & Vienna & The State of Vienna \\
\hline Belgium & Brussels & The Brussels Capital Region \\
\hline Bulgaria & Sofia & The Capital Municipality of Sofia \\
\hline Cyprus & Nicosia & Nicosia Municipality \\
\hline Czech Republic & Prague & The Capital City of Prague \\
\hline Denmark & Copenhagen & Metropolitan Copenhagen - Storkøbenhavn \\
\hline Estonia & Tallinn & Tallinn Municipality \\
\hline Finland & Helsinki & Helsinki Metropolitan Area \\
\hline France & Paris & Île-de-France \\
\hline \multirow[t]{4}{*}{ Germany } & Berlin & The State of Berlin \\
\hline & Düsseldorf & The Urban District (Stadkreise) of Düsseldorf \\
\hline & Frankfurt am Main & The Urban District of Frankfurt am Main \\
\hline & Munich & The Urban District of Munich \\
\hline Greece & Athens & Athens-Piraeus Super-Prefecture \\
\hline Hungary & Budapest & The Capital City of Budapest \\
\hline Iceland & Reykjavik & The Capital Region of Reykjavík \\
\hline Ireland & Dublin & County Dublin \\
\hline \multirow[t]{3}{*}{ Italy } & Milan & The Province of Milan \\
\hline & Rome & The Province of Rome \\
\hline & Turin & The Province of Turin \\
\hline Latvia & Riga & Riga District \\
\hline Lithuania & Vilnius & The Vilnius City Municipality \\
\hline Luxembourg & Luxembourg & Luxembourg City \\
\hline Malta & Valetta & The Municipality of Valletta \\
\hline \multirow[t]{2}{*}{ Netherlands } & Amsterdam & The Municipality of Amsterdam \\
\hline & Rotterdam & The Municipality of Rotterdam \\
\hline Norway & Oslo & Greater Oslo Region \\
\hline Poland & Warsaw & The Capital Municipality of Warsaw \\
\hline \multirow[t]{2}{*}{ Portugal } & Lisbon & Greater Lisbon \\
\hline & Porto & Greater Porto \\
\hline Romania & Bucharest & The Municipality of Bucharest \\
\hline Slovakia & Bratislava & The Municipality of Bratislava \\
\hline Slovenia & Ljubljana & The Municipality of Ljubljana \\
\hline \multirow[t]{2}{*}{ Spain } & Barcelona & The county of Barcelona - Comarca el Barcelonès \\
\hline & Madrid & The Autonomous Community of Madrid \\
\hline Sweden & Stockholm & Greater Stockholm - Storstockholm \\
\hline \multirow[t]{3}{*}{ Switzerland } & Basel & The Cantons of Basel City and Basel-Land \\
\hline & Geneva & The Canton of Geneva \\
\hline & Zürich & The Canton of Zürich \\
\hline UK & London & Greater London \\
\hline Japan & Tokyo & Tokyo Prefecture \\
\hline USA & New York & New York-Northern New Jersey-Long Island MSA \\
\hline
\end{tabular}

